\title{
Effect of crude plant extracts from some Oaxacan flora on two deleterious fungal phytopathogens and extract compatibility with a biofertilizer strain
}

\section{Karla I. Lira-De León ${ }^{1}$, Marco V. Ramírez-Mares' ${ }^{1}$, Vladimir Sánchez-López², Mario Ramírez-Lepe ${ }^{3}$, Raúl Salas-Coronado ${ }^{4}$, Norma F. Santos-Sánchez ${ }^{4}$, Rogelio Valadez-Blanco ${ }^{4}$ and Beatriz Hernández-Carlos ${ }^{4 *}$}

1 Instituto de Recursos, Universidad del Mar, Puerto Ángel, México

2 Instituto de Biotecnología, Universidad del Papaloapan, Tuxtepec, México

${ }^{3}$ Unidad de Investigación y Desarrollo en Alimentos, Instituto Tecnológico de Veracruz, Veracruz, México

${ }^{4}$ Instituto de Agroindustrias, Universidad Tecnológica de la Mixteca, Huajuapan de León, México

\section{Edited by:}

Eva-Guadalupe Lizárraga-Paulín, Universidad Nacional Autonoma De Mexico, Mexico

\section{Reviewed by:}

Marcela Carina Audisio, Instituto de Investigaciones para la Industria Química (INIQUI)-CONICET, Argentina

Amit Kumar Tyagi, The University of Texas MD Anderson Cancer Center, USA

\section{${ }^{*}$ Correspondence:}

Beatriz Hernández-Carlos, Instituto de Agroindustrias, Universidad Tecnológica de la Mixteca, Carretera a Acatlima km 2.5, Huajuapan de León, Oaxaca 69000, Mexico e-mail:bhcarlos@mixteco.utm.mx
The antimicrobial activity of 12 plant extracts was tested against the phytopathogens Alternaria alternata and Fusarium solani. In addition, the compatibility of the extracts toward Bacillus liqueniformis, a biofertilizer and a non-target microorganism, was assessed. Plants tested belong to the Euphorbiaceae, Asteraceae, Crassulaceae, Rubiaceae, Convolvulaceae, Verbenaceae, Orchidaceae, Nyctaginaceae, Boraginaceae, and Tiliaceae families and were collected in the State of Oaxaca. The antifungal activity of the plant extracts $(50-100 \mathrm{mg} / \mathrm{mL})$ against $A$. alternata and F. solani, was determined by measuring the mycelium radial growth and obtaining the minimum inhibitory concentration (MIC) of fungal growth. In addition, with the aim of finding plant extracts which are compatible with a $B$. licheniformis biofertilizer strain and to test the non-toxic nature of the treatments, the toxicity of the extracts toward this strain was evaluated using the agar diffusion method. Azoxystrobin $(12 \mu \mathrm{g})$ and chloramphenicol $(30 \mu \mathrm{g})$ were used as positive controls for the pathogens and for the non-target bacteria, respectively. Plant extracts inhibited fungal growth in the ranges of $0.76-56.17 \%$ against $F$. solani and $2.02-69.07 \%$ against $A$. alternata. The extracts of Acalypha subviscida, Ipomoea murucoides, Tournefortia densiflora and Lantana achyranthifolia showed MIC values between $5.77-12.5 \mathrm{mg} / \mathrm{mL}$ for at least one of the fungal species. The best treatment, Adenophyllum aurantium, exhibited a maximum inhibition for both $F$. solani (56.17\%, MIC $=7.78 \mathrm{mg} / \mathrm{mL}$ ) and $A$. alternata $(68.64 \% \mathrm{MIC}=7.78 \mathrm{mg} / \mathrm{mL})$, and resulted innocuous toward $B$. licheniformis. Therefore, this plant has an outstanding potential for the agroecological control of fungal phytopathogens in industrial crops.

Keywords: filamentous fungi, antifungal activity, plant extracts, Adenophyllum aurantium, Alloispermum integrifolium, Ipomoea murucoides, Tournefortia densiflora, Lantana achyranthifolia

\section{INTRODUCTION}

Species of Alternaria and Fusarium are important plant pathogens which cause significant productivity losses to agriculture worldwide. In Mexico, A. alternata and F. oxysporum cause black molds in tomato ripe fruits (Gastélum and Gálvez-Figueroa, 2002) and blight of pepper crops (Mojica-Marín et al., 2009), respectively. Nowadays, synthetic fungicides are used indiscriminately for the control of these pathogens which not only damage the environment but also are toxic to the final consumers. Botanical fungicides can be used as a healthy and environmentally friendly alternative to synthetic fungicides. To be used in vegetable production it is desirable that these products are specifically toxic to filamentous fungi without damaging non-target organisms. Soil bacteria, such as Bacillus species possess fungicide and biofertilizer activity as they promote plant growth and health, such as B. subtilis, B. pumilus, B. amyloliquefaciens, and
B. licheniformis (Pérez-García et al., 2011; Dimkić et al., 2013). Therefore, Bacillus species can be considered as non-target organisms while assessing new botanical fungicides. On the other hand, some vegetable families have shown fungicide activity against Fusarium and Alternaria species: Asteraceae (Jasso de Rodríguez et al., 2007), Euphorbiaceae (Gamboa-Angulo et al., 2008; Ascacio-Valdés et al., 2013), and Apocyneaceae (Ferreira-Medeiros et al., 2013). However, there are not published studies that assess the effect of plant fungicides on biofertilizer microorganisms such as Bacillus species. Considering this, it is important to search new fungicide plant extracts and to study their compatibility with biofertilizer microorganisms since the use of plant fungicide-biofertilizer treatments represents a better agroecologic alternative than the use of chemical fertilizers and synthetic fungicides. Therefore, in this work, the extracts of 12 plants were tested for their antimicrobial activity 
against Fusarium solani, Alternaria alternata, and also for their compatibility with $B$. liqueniformis. The species tested belong to the Euphorbiaceae, Asteraceae, Crassulaceae, Rubiaceae, Convolvulaceae, Verbenaceae, Orchidaceae, Nyctaginaceae, Boraginaceae, and Tiliaceae families and were collected in the State of Oaxaca, Mexico (Table 1).

\section{MATERIALS AND METHODS CHEMICALS}

All solvents used, methanol, ethyl acetate, ethyl ether and $n$-hexane, were reagent grade (Sigma). Potato dextrose agar (PDA), potato dextrose broth (PDB), potato broth (PB), Mueller Hinton (MH) agar, $\mathrm{MH}$ broth (MHB), trypticase soy agar (TSA), trypticase soy broth (TSB), were purchase from Difco (Sparks, MD). Methanol (HPLC grade), dimethyl sulfoxide (DMSOHybri-Max), and chloramphenicol were obtained from Sigma Chemical (St. Louis, MO). Azoxystrobin (AMISTAR ${ }^{\circledR}$ XTRA) was supplied by Syngenta Crop protection S.A (Macquarie, Australia).

\section{BIOLOGICAL MATERIAL \\ Fungal strains}

Fusarium solani was purchased from the National Collection of microbial and cell cultures of CINVESTAV-IPN (CDBB, Mexico), with a control number CDBB-H-1407.

Alternaria alternata: The VSL302 strain was isolated from tomato plant leaves with symptoms of early blight disease and collected from a commercial greenhouse located in Huajuapan de León (Oaxaca, Mexico) in September 2012. The infected tissue was washed with distilled water for $30 \mathrm{~s}$ followed by a $1 \mathrm{~min}$ immersion in $1 \% \mathrm{v} / \mathrm{v}$ (volume/volume) sodium hypochlorite. Subsequently, the tissue was rinsed three times with distilled water and dried using absorbent paper. Fragments of $0.5 \mathrm{~cm}$ were cut and incubated in PDA medium at $25^{\circ} \mathrm{C}$ for 1 week under $12 \mathrm{~h}$ darkness/ $12 \mathrm{~h}$ cool white fluorescent light.

B. licheniformis MV1 with accession number Genbank KJ190320 was isolated and identified by Valadez-Blanco and collaborators (submitted, Apr, 2014). The strain was grown and maintained on TSA and TSB media, while MH broth and MH agar were used for the experimental tests.

\section{Morphological identification of the fungal isolates}

Fungal isolates were grown on SNA plates (Nirenberg, 1976) at $25^{\circ} \mathrm{C}$ with alternating light/darkness photoperiods $(12 / 12 \mathrm{~h})$ for $7 \mathrm{~d}$. Microscopic observations were carried out from preparations mounted in $3 \% \mathrm{KOH}$ using a bright field and phase contrast Leica DM 300 microscope (Leica Microsystems GmbH Wetzlar, Germany). Morphological characteristics of the colonies, mycelium and conidia of the isolates allowed genera identification using the key of imperfect fungi (Barnett and Hunter, 1998).

\section{Molecular identification of the fungal isolate}

A fungal isolate (VSL302) was grown on PD plates at $25^{\circ} \mathrm{C}$ with alternating light/darkness photoperiods $(12 / 12 \mathrm{~h})$ for $3 \mathrm{~d}$. The mycelium was placed in a microcentrifuge tube and the genomic DNA was extracted using the commercial DNeasy ${ }^{\circledR}$ Plant Mini Kit following the manufacturer's protocol (Qiagen Inc., CA, USA). The amplification of internal transcribed spacers (ITS1, 5.8S, ITS2 rDNA) and the purification of the PCR products were performed according to the work of Sánchez et al. (2007). Purified PCR products were sequenced by MACROGEN (Maryland, USA). Sequence was aligned and matched against the BLAST nucleotide database (http://blast.ncbi.nlm.nih.gov/Blast. cgi) for the molecular identification of the isolate. Phylogenetic

Table 1 | Plants from Oaxaca evaluated against the phytopathogen fungi Fusarium solani and Alternaria alternata.

\begin{tabular}{|c|c|c|c|c|}
\hline Specie (family) & Collection site & Voucher number & $\begin{array}{l}\text { Part plant } \\
\text { used }\end{array}$ & $\begin{array}{l}\text { Extraction } \\
\text { solvent }\end{array}$ \\
\hline Acalypha cuspidata Jacq. (Euphorbiaceae) & B & 25068 & Aerial & $\mathrm{MeOH}$ \\
\hline $\begin{array}{l}\text { Acalypha subviscida S. Watson var. lovelanddii } \\
\text { McVaugh (Euphorbiaceae) }\end{array}$ & A & 24007 & Aerial & $\mathrm{MeOH}$ \\
\hline Alloispermum integrifolium (DC.) H. Rob. (Asteraceae) & A & 24024 & Aerial & $\mathrm{MeOH}$ \\
\hline Adenophyllum aurantium (L.) Strother (Asteraceae) & $\mathrm{C}$ & 25173 & $\begin{array}{l}\text { Aerial } \\
\text { Root }\end{array}$ & $\begin{array}{l}\mathrm{MeOH} \\
\mathrm{MeOH}, \mathrm{AcOEt}\end{array}$ \\
\hline Echeveria acutifolia Lindl. (Crassulaceae) & $\mathrm{D}$ & 25184 & Aerial & $\mathrm{MeOH}$ \\
\hline Galium mexicanum Kunth (Rubiaceae) & A & 23994 & Aerial & $\mathrm{MeOH}$ \\
\hline Ipomoea murucoides Roem. \& Schult. (Convolvulaceae) & $\mathrm{D}$ & 25227 & Leaves & Ether \\
\hline Lantana achyranthifolia Desf. (Verbenaceae) & $\mathrm{D}$ & 25185 & Aerial & $\mathrm{MeOH}$ \\
\hline $\begin{array}{l}\text { Prosthechea varicosa (Lindl.) W. E. Higgins } \\
\text { (Orchidaceae) }\end{array}$ & A & 24054 & $\begin{array}{l}\text { Aerial } \\
\text { Bulbs }\end{array}$ & $\begin{array}{l}\mathrm{MeOH} \\
\mathrm{MeOH}\end{array}$ \\
\hline Salpianthus arenarius Humb. \& Bonpl. (Nyctaginaceae) & C & 25084 & Aerial & $\mathrm{MeOH}$ \\
\hline $\begin{array}{l}\text { Tournefortia densiflora M. Martens \& Galeotti } \\
\text { (Boraginaceae) }\end{array}$ & C & 25221 & $\begin{array}{l}\text { Aerial } \\
\text { Root }\end{array}$ & $\begin{array}{l}\mathrm{MeOH} \\
\mathrm{MeOH}\end{array}$ \\
\hline Heliocarpus terebinthinaceus (DC.) Hochr. (Tiliaceae) & $\mathrm{D}$ & 25225 & Seeds & $\mathrm{H}_{2} \mathrm{O}$, n-Hexane \\
\hline
\end{tabular}

$\mathrm{MeOH}$, methanol; AcOEt, ethylacetate.

A, San Miguel Suchixtepec, Miahuatlán; B, Candelaria Loxicha, San Pedro Pochutla; C, Chepilme Botanic Garden (Universidad del Mar), San Pedro Pochutla; D, Huajuapan de León; E, Ejutla de Crespo. 
construction was made using the ClustalW2 tool (http://www. ebi.ac.uk/Tools/msa/clustalw2/).

\section{Plant material}

Twelve plant species were collected in the State of Oaxaca (Mexico) between October 2010 and July 2012. These plants were identified by specialists of the Universidad Nacional Autonoma de Mexico (UNAM) and the Universidad Autonoma de Chapingo (UACh). Plant specimens were deposited in the "Jorge Salas Espinoza" Herbarium of the UACh. Plant parts, scientific name, collection site, voucher number, and extraction solvent are listed in Table 4. Plant samples were left to dry at room temperature without sunlight exposure. Samples were subsequently chopped and stored in a cool and dry place before further processing.

\section{Preparation of extracts}

Extracts were prepared from aerial parts except for those indicated in Table 1, for which the bulbs (B) or the roots (R) were used. Pulverized vegetal material, except I. murucoides and H. terebinthinaceus, was soaked in $1000 \mathrm{ml}$ of methanol $(\mathrm{MeOH})$ for 2 weeks at room temperature $\left(25^{\circ} \mathrm{C}\right)$. Each extract was filtered through a Whatman No. 1 filter paper and the solvent was eliminated using a rotary evaporator at $50^{\circ} \mathrm{C}$ under reduced pressure. Methanol extract of $A$. aurantium roots was partitioned with AcOEt and the solvent was eliminated.

The dried and ground mixture of the leaves ( $100 \mathrm{~g}$ ) of I. murucoides was ultrasonic-assisted extracted with $1 \mathrm{~L}$ of $\mathrm{MeOH}$ acid solution $\mathrm{MeOH}(990 \mathrm{MeOH}+10 \mathrm{~mL} \mathrm{AcOH} \mathrm{pH} \mathrm{4)} \mathrm{in} \mathrm{a} \mathrm{soni-}$ cation cleaning bath operated at a frequency of $40 \mathrm{kHz}$ and an ultrasonic input power of $180 \mathrm{~W}$ with a useable volume of $6 \mathrm{~L}$ (Ultrasonic bath SN-3200 DTN, CE). The extraction was performed by $20 \mathrm{~min}$ (twice times) at room temperature. Then, the combined extract was filtered and the solvent evaporated to dryness under reduced pressure. The crude extract was suspended in diluted $\mathrm{AcOH}(1 \% \mathrm{v} / \mathrm{v}, 100 \mathrm{~mL}$ at $\mathrm{pH} 4)$ and was extracted with $\mathrm{Et}_{2} \mathrm{O}(8 \times 125 \mathrm{~mL})$. The $\mathrm{Et}_{2} \mathrm{O}$ sub-index extracts were combined, dried over $\mathrm{Na}_{2} \mathrm{SO}_{4}$, filtered and concentrated under reduced pressure to afford an $\mathrm{Et}_{2} \mathrm{O}$ soluble part.

The dried and ground mixture of the seeds $(100 \mathrm{~g})$ of $\mathrm{H}$. terebinthinaceus was ultrasonic-assisted extracted with $700 \mathrm{~mL}$ of aqueous $\mathrm{EtOH}(90 \% \mathrm{v} / \mathrm{v})$ in a sonication cleaning bath operated at a frequency of $40 \mathrm{kHz}$ and an ultrasonic input power of $180 \mathrm{~W}$ with a useable volume of $6 \mathrm{~L}$ (Ultrasonic bath SN3200 DTN, CE). The extraction was performed by $30 \mathrm{~min}$ (three times) at room temperature. Then, the combined extract was filtered and the solvent evaporated to dryness under reduced pressure. The crude extract was suspended in $\mathrm{H}_{2} \mathrm{O}(200 \mathrm{~mL})$ and was extracted with hexane $(4 \times 200 \mathrm{~mL})$. The hexane extracts were combined, dried over $\mathrm{Na}_{2} \mathrm{SO}_{4}$, filtered and concentrated under reduced pressure to afford a hexane soluble part. The aqueous solution was extracted with AcOEt $(4 \times 200 \mathrm{~mL})$, and was dried over $\mathrm{Na}_{2} \mathrm{SO}_{4}$, filtered and concentrated under reduced pressure. To the remaining $\mathrm{MeOH}$ aqueous solution was added $\mathrm{MeOH}$ to afford a beige precipitate. The dried and powdered crude extracts were kept at $4^{\circ} \mathrm{C}$ and protected from light and moisture until further use. Saturated solutions in DMSO (Table 2) of each extract were prepared prior to their use.
Table 2 | Percent of inhibitory activity on mycelial radial growth of $F$ solani and $A$. alternata produced by crude plant extracts.

\begin{tabular}{|c|c|c|c|}
\hline \multirow[t]{2}{*}{ Treatment } & \multirow{2}{*}{$\frac{\text { Conc. }}{\mathrm{mg} / \mathrm{mL}}$} & \multicolumn{2}{|c|}{ Fungi strains } \\
\hline & & F. solani & A. alternata \\
\hline Azoxystrobin (positive control) & 0.060 & $74.30 \pm 5.96$ & $61.17 \pm 6.93$ \\
\hline Adenophyllum aurantium & 100 & $7.40 \pm 8.46^{*}$ & $9.55 \pm 6.79^{*}$ \\
\hline Adenophyllum aurantium $\mathrm{R}$ & 100 & $7.34 \pm 1.17^{*}$ & $2.02 \pm 10.16^{*}$ \\
\hline Adenophyllum aurantium R-AcOEt & 100 & $56.17 \pm 3.38 *$ & $68.64 \pm 1.97$ \\
\hline Acalypha cuspidata & 50 & $4.66 \pm 3.72 *$ & $-24.92 \pm 2.25^{*}$ \\
\hline Acalypha subviscida & 100 & $16.31 \pm 1.68 *$ & $5.79 \pm 9.25^{*}$ \\
\hline Alloispermum integrifolium & 100 & $3.81 \pm 3.29^{*}$ & $6.09 \pm 6.32^{*}$ \\
\hline Echeveria acutifolia & 71 & $17.54 \pm 1.37^{*}$ & $-38.92 \pm 7.28^{*}$ \\
\hline Galium mexicanum & 50 & $10.90 \pm 1.66^{*}$ & $5.09 \pm 4.10^{*}$ \\
\hline Lantana achyrantifolia & 100 & $12.15 \pm 0.87^{*}$ & $10.77 \pm 4.47^{*}$ \\
\hline Prostechea varicosa $B$ & 50 & $-5.25 \pm 2.58 *$ & $-41.44 \pm 3.18^{*}$ \\
\hline Prostechea varicosa $R$ & 50 & $4.39 \pm 2.11^{*}$ & $3.40 \pm 3.01 *$ \\
\hline Salpianthus arenarius & 67 & $1.05 \pm 3.78^{*}$ & $-11.86 \pm 3.94^{*}$ \\
\hline Tournefortia densiflora & 100 & $0.76 \pm 6.06^{*}$ & $-22.05 \pm 5.78^{*}$ \\
\hline Tournefortia densiflora $\mathrm{R}$ & 70 & $52.42 \pm 1.96^{*}$ & $69.07 \pm 2.00$ \\
\hline Heliocarpus terebinthinaceus S-Aq & 100 & $28.74 \pm 1.40^{*}$ & $-18.11 \pm 3.83^{*}$ \\
\hline Heliocarpus terebinthinaceus S-Hx & 200 & $15.78 \pm 3.49 *$ & $-17.32 \pm 8.29 *$ \\
\hline Ipomoea murucoides $\mathrm{Et}_{2} \mathrm{O}$ & 100 & $28.19 \pm 2.96^{*}$ & $-25.45 \pm 4.92^{*}$ \\
\hline
\end{tabular}

$B$, bulb; $R$, root; $S$, seeds. Aerial parts were used for rest of plants.

The extracting solvent is $\mathrm{MeOH}$ except when otherwise is indicated. AcOEt, ethylacetate; $A q$, aqueous; $H x$, hexane; $E t_{2} O$, ethyl ether.

Results are expressed as the mean \pm S.D. $(n=3)$.

Data were analyzed by One-Way ANOVA followed by Dunnett test.

${ }^{*}$ Significant difference between each treatment and the positive control are shown as $p<0.05$.

\section{Inhibitory activity on radial growth of fungi}

To evaluate the mycelial growth inhibition of the fungal pathogens by the vegetable extracts, $F$. solani and A. alternata were cultivated for $5 \mathrm{~d}$ at $25^{\circ} \mathrm{C}$ on PDA; the mycelia was harvested and used for the radial growth assays. Following this, $20 \mu \mathrm{L}$ of each treatment (DMSO, azoxystrobin or plant extract) was put in the center of a PDA plate ( $60 \mathrm{~mm}$ diameter). Azoxystrobin is a commercial synthetic fungicide and was used in this study as the positive control. When the treatments were absorbed into the agar, a $5 \mathrm{~mm}$ diameter size plug from the PDA fungal cultures was inoculated on the center of the plate. Each assay was replicated three times. The cultures were incubated for $5 \mathrm{~d}$ at $28^{\circ} \mathrm{C}$ and exposed to white light. The radial mycelial growth was determined after $5 \mathrm{~d}$ by calculating the mean of two perpendicular mycelial-growth diameters for each replicate. The inhibitory activity to radial growth (IR) was calculated according to the following formula (Pinto et al., 1998):

$$
\% \mathrm{IR}=\frac{\mathrm{Dc}-\mathrm{Dt}}{\mathrm{Dc}}
$$

where IR $=$ percentage of mycelial growth inhibition, $\mathrm{Dc}=$ average diameter of the fungal mycelial-growth of the negative control (DMSO), Dt $=$ average diameter of the fungal mycelial-growth treated with the extracts or the positive control.

According to the availability of extracts and their growth inhibition results, extracts of A. aurantium, A. subviscida, G. 
mexicanum, and L. achyranthifolia were screened at three concentrations for mycelia inhibition of both fungi. Additionally, A. integrifolium, and E. acutifolia were tested against F. solani. Each treatment was diluted in a 1:0, 1:2, and 1:4 ratio and screened for mycelia inhibition following the same methodology described above.

\section{Determination of the minimal inhibitory concentration}

The MIC was obtained for all the extracts by using a two-fold broth dilution method according to Sasidharan et al. (2012). Sterile PDB medium $(300 \mathrm{~mL})$ supplemented with $0.2 \%$ Tween 80 $(\mathrm{v} / \mathrm{v})$ was inoculated with a pathogenic fungus using $5 \mathrm{~d}$ cultures grown in $6 \mathrm{~mm}$ diameter disks (10). Subsequently, the culture was incubated at $28^{\circ} \mathrm{C}$ for $7 \mathrm{~d}$ at $150 \mathrm{rpm}$ with white light exposure. After that, the culture was poured into a sterile Erlenmeyer flask with $100 \mathrm{~mL}$ of distilled water supplemented with $0.2 \%$ Tween $80(\mathrm{v} / \mathrm{v})$ and stirred with a magnetic bar for $30 \mathrm{~min}$. The resulting solution, containing the spores, was filtered through a sterile gauze. The spore concentration was adjusted to $10^{4}$ spores $/ \mathrm{mL}$. The treatments were prepared according to the maximum extract concentration used in the antifungal assay plate. $200 \mu \mathrm{L}$ of the treatment (DMSO, azoxystrobin or plant extract) was mixed with $800 \mu \mathrm{L}$ of sterile water to get an X treatment concentration $(\mathrm{mg} / \mathrm{mL})$; a $0.60 \mathrm{mg} / \mathrm{mL}$ concentration was used for the azoxystrobin treatment. Ten sterile test tubes were arranged in a test tube rack and $1 \mathrm{~mL}$ of sterile water and $0.2 \%$ Tween $80(\mathrm{v} / \mathrm{v})$ (emulsifying agent) was pipetted into each test tube. Subsequently, a twofold serial dilution of the $\mathrm{X}$ treatment concentration was performed. The pathogen inoculum $\left(1 \mathrm{~mL}, 10^{4}\right.$ spores $/ \mathrm{mL}$ ) was pipetted into each of the test tubes containing the treatment, thus obtaining the final treatment concentrations: $\mathrm{X} / 4$, $\mathrm{X} / 8, \mathrm{X} / 16, \mathrm{X} / 32, \mathrm{X} / 64, \mathrm{X} / 128, \mathrm{X} / 256, \mathrm{X} / 512, \mathrm{X} / 1024$, and X/2048. Finally, the tubes were incubated at $28^{\circ} \mathrm{C}$ for $7 \mathrm{~d}$, in the shaking incubator at $150 \mathrm{rpm}$ and exposed to white light. The MIC value was determined as the lowest concentration of plant extract that completely inhibited the visible growth of the fungal pathogenic strains. Each assay was carried out in triplicate.

\section{Compatibility of the plant extracts with B. licheniformis MV1}

The effect of the vegetable extracts on B. licheniformis MV1 growth was evaluated by the agar diffusion method (Bauer et al., 1966). The strain was cultured on TSA plates at $37^{\circ} \mathrm{C}$ for $24 \mathrm{~h}$. Following this, $4 \mathrm{~mL}$ of $\mathrm{MHB}$ was inoculated with the strain and incubated for $2 \mathrm{~h}$ at $37^{\circ} \mathrm{C}$. This culture was adjusted to the 0.5 MacFarland standard $\left(0.048 \mathrm{M} \mathrm{BaCl}_{2} 0.5 \mathrm{~mL}+0.18 \mathrm{M} \mathrm{H}_{2} \mathrm{SO}_{4}\right.$ $99.5 \mathrm{~mL}$ ) for the susceptibility test. MHA dishes were impregnated with $150 \mu \mathrm{L}$ of the adjusted strain suspension using sterile cotton swabs. Chloramphenicol $(30 \mu \mathrm{g})$ and DMSO $(25 \mu \mathrm{L})$ were used as positive and negative controls, respectively. Treatment application $(25 \mu \mathrm{L})$ was performed directly on the solid medium (Table 1). The plates were incubated at $37^{\circ} \mathrm{C}$ for $24 \mathrm{~h}$, and the diameter of the inhibition zones (I.D.) was measured. All assays were carried out in triplicate.

\section{STATISTICAL ANALYSIS}

Data are shown as mean \pm SD of three different experiments. Statistical analyses were performed using a One-Way ANOVA, with Dunnett post test. All comparisons were made relative to positive control and significant difference was indicated as ${ }^{*} p<0.05$. Growth inhibition results at three concentration levels were compared using Tukey's studentized range (HSD) test, with a $p=0.05$ using the SAS ${ }^{\circledR}$ v.8.0 software (USA).

\section{RESULTS}

\section{IDENTIFICATION OF THE FUNGAL ISOLATE}

The mycelium of the fungal colonies grown on synthetic nutrientpoor agar (SNA) plates was greenish gray at the beginning of the incubation and greenish black after 7 days of incubation. Conidia were obclavate and ellipsoidal and had both cross and longitudinal septa. The isolate ribosomal DNA region containing the ITS1-5.8s-ITS2 sequence was amplified from genomic DNA using the primers ITS 1 and ITS4. The amplified region showed a 99\% homology with Alternaria alternata strains (GeneBank KF039678, JX241640, JN673372). A neighbor joining (NJ) tree (Figure 1) was obtained after aligning the ITS1-5.8s-ITS2 sequence of A. alternata VSL302 with 24 other GenBank-retrieved sequences, representing known Alternaria species from 22 different sections of Alternaria (Woudenberg et al., 2013). In particular, A. alternata VSL302 grouped with $A$. arborescens AF347033 and A. alternata AF347031 that belong to the taxonomic section of Alternata. Thus, based on the phenotype characteristics and by sequence analysis of the ITS gene, the VSL302 isolate was identified as A. alternata.

\section{INHIBITORY ACTIVITY ON MYCELIAL RADIAL GROWTH}

The results of the mycelial growth assay are listed in Table 2. Concentration of each extract was based on its maximum solubility in DMSO and the amount applied into each plate was based on the minimum volume capable of diffusing into the agar $(20 \mu \mathrm{L})$. The low extract solubility is due to the fact that all the extracts contained non-polar compounds, except $H$. terenbithinaceous aqueous extract, which could be observed in the solubility tests. Root extracts of A. aurantium R-AcOEt $(100 \mathrm{mg} / \mathrm{mL})$ and $T$. densiflora $\mathrm{R}(70 \mathrm{mg} / \mathrm{mL})$ had the maximum mycelial inhibition on F. solani (56.17 and $52.42 \%$, respectively) and A. alternata (68.64 and $69.07 \%$, respectively). The inhibition of the positive control $(0.012 \mathrm{mg} / \mathrm{mL})$ was 74.30 \pm 5.96 and $61.17 \pm 6.93 \%$ for $F$. solani and A. alternaria, respectively. Other extracts, such as those from L. achyranthifolia, $H$. terenbinthinaceus Ac, $H$. terenbinthinaceus $\mathrm{Hx}, I$. murucoides and $A$. subviscida, also presented some antifungal activity $(10-28.7 \%)$. On the other hand, eight extracts stimulated the mycelial growth of $A$. alternata $(-11.86 \pm 3.94$ to $-41.44 \pm 3.18 \%$ ), while one stimulated that of $F$. solani $(-5.25 \pm 2.58 \%)$.

The effect of the dilution of the extracts on the activity against F. solani probed to be dose-independent, except for A. aurantium R AcOEt, E. acutifolia, and L. achyranthifolia extracts. The activity of A. aurantium and L. achyranthifolia extracts was reduced when treatments were diluted 1:2 and 1:4 (Figure 2). On the other hand, dose-dependent activity against A. alternata was observed only for the A. subviscida extract, whose inhibitory effect switched to not inhibition and growth promotion when the treatments were diluted 1:2 and 1:4, respectively (Figure 3). Similar results 


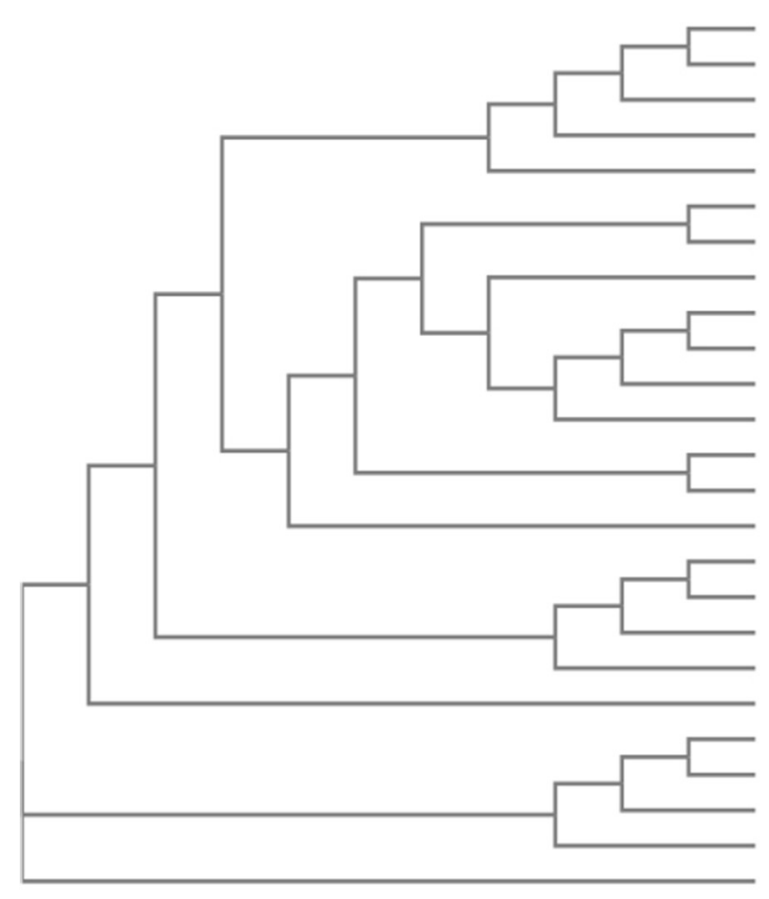

A.alternataVSL302 0.00206

A.arborescens-AF347033 -0.00014

A.alternata-AF347031 -0.00011

A.alternantherae-KC584179 0.02629

A.cinerariae-KC584190 0.01791

A. planifunda- $\mathrm{FJ} 3573150.00988$

A.anigozanthi-KC584180 0.02919

A.telluster-FJ357316 0.02388

A.armoraciae-KC584182 0.01768

A.conjuncta-FJ266475 0.01922

A.caricis-AY278839 0.02815

A.phragmospora-JN383493 0.01237

A.avenicola-KC584183 0.0093

A.dauci-KC584192 0.0182

A.leucanthemi-KC584240 0.02555

A.capsici-annui-KC584187 0.00487

A. penicillata-KC584229 0.00435

A.japonica-KC584201 0.00811

A.brassicicola-JX49903 0.0273

A.carotincultae-KC584188 0.00644

A.cantlous-KC584245 0.00443

A.chartarum-AF229488 0.00339

A.sp.-KC584214 0.00984

A.simsimi-Jf780937 0.01418

A.axiaeriisporifera-KC584184 0.01247

FIGURE 1 | Neighbor-joining (NJ) tree of ITS1-5.8s-ITS2 from Alternaria alternata VSL302. The tree is based on ITS1-5.8s-ITS2 sequences of 24 strains of Alternaria. Each strain correspond to a taxonomic section of the genus Alternaria. It is observed that $A$. alternata VSL302 grouped with the strains that correspond to the genus and species Alternaria alternata (A. arborescens AF347033 and A. alternata AF347031). The NJ tree was generated with the PAUP program using the neighbor-joining method. Numbers on branches indicate bootstrap values from an analysis of 1000 replicates.

\section{F. solani}

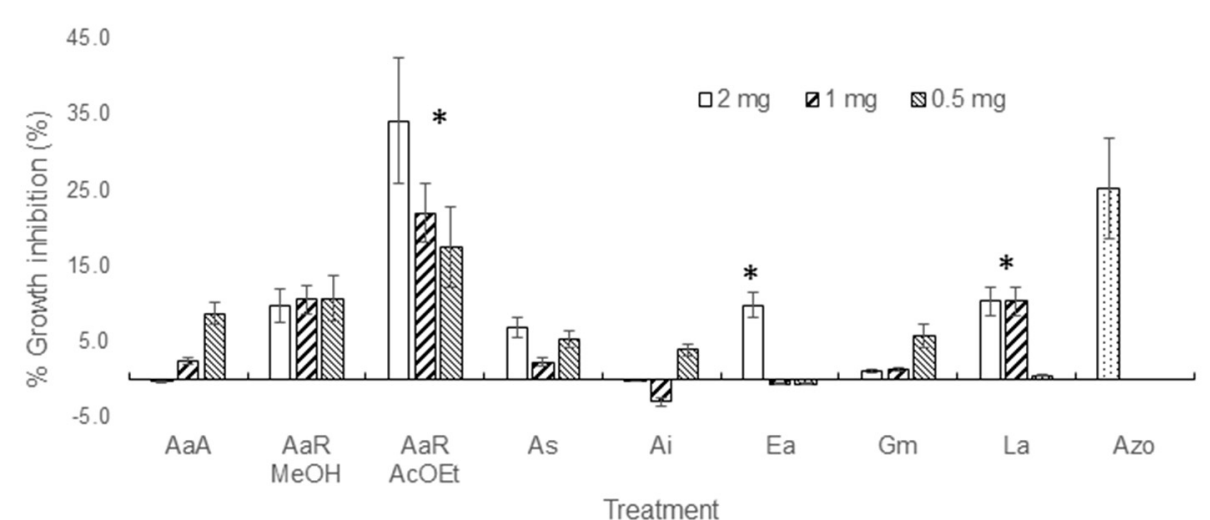

FIGURE 2 | Zone of inhibition (\%) due to methanol extracts of aerial part ( $\mathrm{AaA}$ ) and roots (AaR MeOH and $\mathrm{AaR} \mathrm{AcOEt}$ ) of $A$. aurantium, aerial parts of $A$. subviscida (As), A. integrifolium (Ai), E. acutifolia (Ea), G. mexicanum $(\mathrm{Gm})$, and $L$. achyranthifolia (La) at different concentrations against $\boldsymbol{F}$ solani. Vegetable specie, $\mathrm{R}=$ roots and solvent methanol $(\mathrm{MeOH})$ or ethylacetate (AcOEt) are indicated by abbreviations between parenthesis. Different responses observed at three concentrations are marked $\left(^{*}\right)$ (Tukey; $\left.P=0.05\right)$. Azo; azoxystrobin $(0.012 \mathrm{mg}$ ). were observed for the E. acutifolia extract activity against F. solani (Figure 2).

\section{MINIMAL INHIBITORY CONCENTRATION}

Table 3 shows the minimal inhibitory concentration (MIC) determined as the lowest concentration at which no growth occurs (Sasidharan et al., 2012). I. murucoides extract showed the best antifungal activity on $F$. solani (MIC $=5.77 \mathrm{mg} / \mathrm{mL})$, followed by L. achyranthifolia on A. alternata ( $\mathrm{MIC}=6.25 \mathrm{mg} / \mathrm{mL}$ ), A. aurantium AcOEt on both strains $(\mathrm{MIC}=7.78 \mathrm{mg} / \mathrm{mL}$ ), and A. subviscida on A. alternata (MIC $=8.51 \mathrm{mg} / \mathrm{mL}$ ). The extracts MIC values ranged from 38.5 to 56.8 times the value of the 


\section{A. alternata}

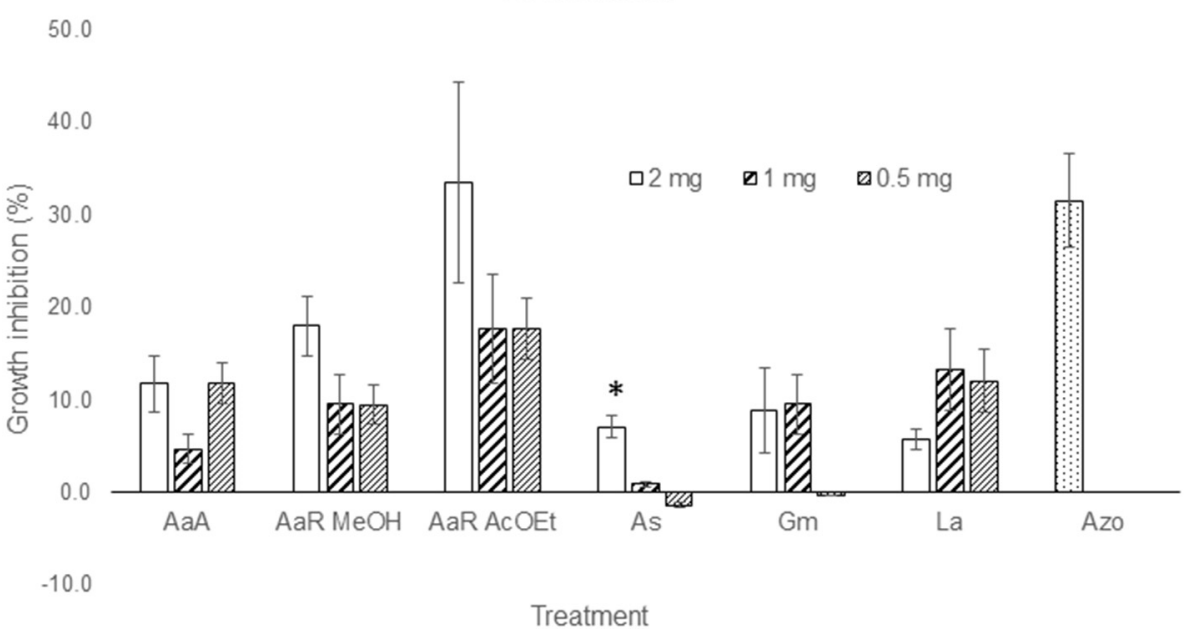

FIGURE 3 | Zone of inhibition (\%) due to methanol extracts of aerial part ( $\mathrm{AaA})$ and roots (AaR $\mathrm{MeOH}$ and $\mathrm{AaR} \mathrm{AcOEt})$ of $A$. aurantium, aerial parts of $A$. subviscida (As), G. mexicanum $(\mathrm{Gm})$, and L. achyranthifolia (La) at different concentrations against $A$. alternata.

Table 3 | Antifungal activities (MIC) of crude plant extracts of some plants from Oaxaca against $F$ solani and $A$. alternata.

\begin{tabular}{lcc}
\hline \multirow{2}{*}{ Treatment } & \multicolumn{2}{c}{ MIC (mg/ml) } \\
\cline { 2 - 3 } & F solani & A. alternata \\
\hline Azoxystrobin (positive control) & 0.15 & 0.15 \\
Adenophyllum aurantium & $27.73^{*}$ & $27.73^{*}$ \\
Adenophyllum aurantium R & $20.00^{*}$ & $20.00^{*}$ \\
Adenophyllum aurantium R-AcOEt & $7.78^{*}$ & $7.78^{*}$ \\
Acalypha cuspidata & $12.50^{*}$ & $12.50^{*}$ \\
Acalypha subviscida & $\mathrm{NEG}$ & $8.51^{*}$ \\
Alloispermum integrifolium & $33.76^{*}$ & $16.88^{*}$ \\
Echeveria acutifolia & $17.75^{*}$ & $17.75^{*}$ \\
Galium mexicanum & $15.00^{*}$ & $15.00^{*}$ \\
Lantana achiranthifolia & $12.50^{*}$ & $6.25^{*}$ \\
Prostechea varicosa-B & $\mathrm{NEG}$ & $\mathrm{NEG}$ \\
Prostechea varicosa-R & $\mathrm{NEG}$ & $14.70^{*}$ \\
Salpianthus arenarius & $\mathrm{NEG}$ & $\mathrm{NEG}$ \\
Tournefortia densiflora & $11.75^{*}$ & $11.75^{*}$ \\
Tournefortia densiflora R & $16.13^{*}$ & $16.13^{*}$ \\
Heliocarpus terebinthinaceus S-Ac & $\mathrm{NEG}$ & $\mathrm{NEG}$ \\
Heliocarpus terebinthinaceus S-Hx & $50^{*}$ & $50^{*}$ \\
Ipomoea murucoides-Et ${ }_{2} \mathrm{O}$ & $5.77^{*}$ & $11.54^{*}$ \\
\hline
\end{tabular}

$B$, bulb; $R$, root; $S$, Seeds. Aerial parts were used for rest of plants. The extracting solvent is $\mathrm{MeOH}$ except when otherwise is indicated. AcOEt, ethylacetate; $A q$, aqueous; $H x$, hexane; $E t_{2} O$, ethyl ether.

$N E G$, Negative (unable to inhibit the fungi growth).

Data were analyzed by One-Way ANOVA followed by Dunnett test.

${ }^{*}$ Significant difference between each treatment and the positive control are shown as $p<0.05$.

positive control $(\mathrm{MIC}=0.15 \mathrm{mg} / \mathrm{mL})$. The rest of the extracts had MIC values from $11.54-50 \mathrm{mg} / \mathrm{mL}$ or were unable to inhibit fungal growth.
Vegetable specie, $\mathrm{R}$ = roots and solvent methanol $(\mathrm{MeOH})$ or ethylacetate (AcOEt) are indicated by abbreviations between parenthesis. Different responses observed at three concentrations are marked $\left(^{*}\right.$ ) (Tukey; $P=0.05)$. Azo; azoxystrobin $(0.012 \mathrm{mg}$.

\section{INHIBITION OF B. LICHENIFORMIS MV1 GROWTH}

The A. aurantium R-AcOEt extract (Table 4) resulted in a low growth inhibition of the bacteria $(1.56 \pm 1.81 \mathrm{~mm})$. On the other hand, T. densiflora $\mathrm{R}$ caused a significant growth inhibition $(14.60 \pm 1.02 \mathrm{~mm})$ in comparison with the value obtained by the positive control, chloramphenicol $(20.93 \pm 0.20 \mathrm{~mm})$. Other extracts with low or null inhibitory activities were $H$. terenbinthinaceous Aq $(1.56 \pm 0.28 \mathrm{~mm})$, A. integrifolium $(0.00 \pm 0.0 \mathrm{~mm})$, A. aurantium A $(3.48 \pm 0.79 \mathrm{~mm})$ and $A$. aurantium $\mathrm{R}(0.0 \pm 0.0 \mathrm{~mm})$.

\section{DISCUSSION}

\section{ANTIFUNGAL ACTIVITY}

F. solani was the pathogenic strain with more susceptibility to mycelial growth inhibition caused by four extracts (I. murucoides, $H$. terenbithinaceous, $T$. densiflora $\mathrm{R}$, and $A$. aurantium $\mathrm{R}$ AcOEt), which showed inhibition percentages greater than $20 \%$. MIC values lower than $10 \mathrm{mg} / \mathrm{mL}$ were obtained for $F$. solani with two extracts (A. aurantium-R AcOEt, and I. murucoides). On the other hand, only two extracts displayed inhibition percentages greater than $20 \%$ for A. alternata ( $T$. densiflora $\mathrm{R}$, and A. aurantium $\mathrm{R}$ AcOEt). However, MIC values lower than $10 \mathrm{mg} / \mathrm{mL}$ were obtained for this strain with three extracts (A. aurantium-R AcOEt, A. subviscida and L. achyranthifolia). Therefore, A. alternata was the most sensitive strain to sporulation inhibition and F. solani was more sensitive to mycelial growth inhibition.

Root extracts of A. aurantium AcOEt and T. densiflora had the highest mycelial growth inhibition against both pathogenic strains. In Oaxaca, the aerial parts of these vegetable species are used to treat infectious diseases (Alonso-Castro et al., 2011). Osuna et al. (2005) reported that T. densiflora leaves had antimicrobial activity against bacteria causing intestinal infections. However, the toxic activity of Tournefortia species against filamentous fungi has not been previously reported. At a family 
Table 4 | Toxic activity of some plants of Oaxaca against the growth of B. licheniformis MV1.

\begin{tabular}{lcc}
\hline Treatment & $\begin{array}{c}\text { Inhibition } \\
\text { zone }(\mathbf{m m})\end{array}$ & $\begin{array}{c}\text { Standard } \\
\text { deviation }\end{array}$ \\
\hline Chloramphenicol (positive control) & 20.93 & 0.20 \\
Adenophyllum aurantium & $3.48^{*}$ & 0.79 \\
Adenophyllum aurantium R & $0.00^{*}$ & 0.00 \\
Adenophyllum aurantium R-AcOEt & $1.56^{*}$ & 1.81 \\
Acalypha cuspidata & $10.06^{*}$ & 0.55 \\
Acalypha subviscida & 21.43 & 0.49 \\
Alloispermum integrifolium & $0.00^{*}$ & 0.00 \\
Echeveria acutifolia & $14.57^{*}$ & 0.61 \\
Galium mexicanum & $18.02^{*}$ & 0.80 \\
Lantana achyrantifolia & $15.93^{*}$ & 0.45 \\
Prostechea varicosa B & $10.42^{*}$ & 1.40 \\
Prostechea varicosa R & $14.36^{*}$ & 1.29 \\
Salpianthus arenarius & $11.43^{*}$ & 1.34 \\
Tournefortia densiflora & 21.19 & 1.87 \\
Tournefortia densiflora $\mathrm{R}$ & $14.60^{*}$ & 1.02 \\
Heliocarpus terebinthinaceus S-Ac & $1.56^{*}$ & 0.28 \\
Heliocarpus terebinthinaceus S-Hx & $13.23^{*}$ & 1.58 \\
Ipomoea murucoides - Et ${ }_{2} \mathrm{O}$ & $13.21^{*}$ & 0.72 \\
\hline B. Bub; &
\end{tabular}

$B, B u l b ; R$, root; $S$, seeds. Aerial parts were used for rest of plants.

The extracting solvent is $\mathrm{MeOH}$ except when otherwise is indicated. AcOEt, ethylacetate; $A q$, aqueous; $H x$, hexane; $E t_{2} O$, ethyl ether.

Results are expressed as the mean \pm S.D. $(n=3)$.

Data were analyzed by One-Way ANOVA followed by Dunnett test.

* Significant difference between each treatment and the positive control are shown as $p<0.05$.

level, some Boraginaceae species are toxic toward Aspergillus niger, A. flavus, Rhizoctonia phaseoli (4 mg/disk; mycelial inhibition $>50 \%$ ) and $R$. solani ( $\mathrm{IC}_{50} 0.180 \mathrm{mg} / \mathrm{mL}$ ) (Jain et al., 2000; Hernández et al., 2007). Methanol extracts from aerial and root parts of $A$. aurantium were not toxic to any fungal species, but $A$. aurantium ethyl acetate (AcOEt) extracts from roots showed a significant antifungal activity against both fungi strains, with mycelial growth inhibition greater than $50 \%$ and a MIC value of $7.78 \mathrm{mg} / \mathrm{mL}$. Adenophyllum genus belonging to the subtribe pectidinae is characterized by the presence of thiophenes as 5-(4-hydroxy-1-butenyl)-2-2'-bithienyl, 5-(4 acetoxybutenyl)-2,2'-bithienyl, and $\alpha$-terthienyl (Downum et al., 1985). This kind of thiophenes inhibited in vitro spore germination and mycelial growth of two F. oxysporum strains at concentrations within the $\mu \mathrm{g} / \mathrm{mL}$ scale (Kourany and Arnason, 1988). There are reports about the phototoxicity of thiophenes through singlet oxygen or free radicals formation (Evans et al., 1986) which in turn causes damage to the membranes. Arnason et al. (1998) reported this effect in which the thiophene phenylheptatriyne inhibited ${ }^{14} \mathrm{C}$ phenylalanine uptake and respiration and enhanced $\mathrm{K}^{+}$leakage in Fusarium culmorum. Additionally, a terthiophene derivative led to a phospholipid peroxidation chain and oxidative damage of membrane proteins through a triplet state of the derivative (Saito et al., 2001). Therefore, the mycelial growth inhibition observed by $A$. aurantium roots extracts was probably caused by the disruption of the membrane functions.

The antibacterial activity of some of these extracts has been reported for I. murucoides (Corona-Castañeda et al., 2013),
G. mexicanum (Bolívar et al., 2011) and L. achyranthifolia (Hernández et al., 2008). In this study, the extracts of I. murucoides and L. achyranthifolia had MIC values of $5.77 \mathrm{mg} / \mathrm{mL}$ against $F$. solani and $6.25 \mathrm{mg} / \mathrm{mL}$ against A. alternata. No activity against filamentous fungi has been reported for these species. Some authors have described species of the Lantana and Ipomoea genus with toxic activity against filamentous fungi: L. camara was toxic to Alternaria spp. (15 mg/mL, mycelial growth inhibition $>50 \%$ ) (Srivastava and Singh, 2011) and to Fusarium oxysporum $(\mathrm{MIC}=0.08-2.5 \mathrm{mg} / \mathrm{mL}$ ) (Mdee et al., 2009), whereas I. batatas was toxic to Rhizopus stolonifer $\left(\mathrm{EC}_{50}=2.2 \mathrm{~g} / \mathrm{l}\right)$ (Stange et al., 2001).

A significant antifungal activity of $H$. terebinthinaceous seed extracts was expected since these extracts contain the flavonoid tiliroside $(0.59 \%)$ (Santos-Sánchez et al., 2014). This flavonoid was also isolated from Picea neoveitchii and showed a mycelial growth inhibition of $55.6 \pm 5.1 \%(100 \mu \mathrm{g} /$ disk $)$ against Alternaria mali (Chen et al., 2012). On the contrary, H. terebinthinaceous extracts slightly increased the mycelial growth of $A$. alternata $(-18.11 \pm 3.83$ and $-17.32 \pm 8.29 \%$, with the Aq and $\mathrm{Hx}$ extracts, respectively) (Table 2 ).

The antifungal activity of E. acutifolia and A. subviscida has not been studied. These extracts had moderate antifungal activity against F. solani. The extract of E. acutifolia, a Crassulaceae, showed a value of $17.54 \pm 1.37 \%$ as mycelial growth inhibition percentage against $F$. solani, which can be considered a weak response. Antifungal species from the Crassulaceae family with antifungal activity are not common, e.g., Sedum ooxypetalum (Navarro-García et al., 2003) and S. acre (Stanković et al., 2012) which showed toxicity to Aspergillus niger (MIC $=8-20 \mathrm{mg} / \mathrm{mL}$ ). The extract of Acalypha cuspidata showed not significant antifungal activity but $A$. subviscida slightly reduced mycelial growth of F. solani $(16.31 \pm 1.68 \%)$ and showed one of best MIC values $(8.51 \mathrm{mg} / \mathrm{mL})$ against $A$. alternata. Therefore, this species should be considered as a good candidate against filamentous fungi together with other Acalypha species reported in the literature with MIC values of $9.5-16.5 \mathrm{mg} / \mathrm{mL}$ for A. hispida (Ejechi and Souzey, 1999) and 1-4 mg/mL for A. diversifolia and Acalypha sp. (Niño et al., 2012). Other fungicides belonging to the Acalypha genus are A. gaumeri, A. wilkesiana, and A. indica (Alade and Irobi, 1993; Gamboa-Angulo et al., 2008; Devi et al., 2013; Maya and Thippanna, 2013).

The extracts of $S$. arenarius (Nyctaginaceae) and P. varicosa (Orchidaceae) showed no toxic significant fungicide activities, except for $P$. varicosa $\mathrm{R}$ against $A$. alternata with a MIC value of $14.70 \mathrm{mg} / \mathrm{mL}$. Toxic activity toward filamentous fungi related to Nyctaginaceae species has not been reported, whereas reports for the Orchidaceae species are scarce; e.g., Nervilia aragoana (Reddy et al., 2010) and Cypripedium macronthos (Shimura et al., 2007).

Essential oils mixtures and extracts from plants with fungicide potential reported elsewhere possess MIC values of 0.03 $2.5 \mathrm{mg} / \mathrm{mL}$, which are 4-100 times greater than those of positive controls such as ketoconazole or azoxystrobin (Svetaz et al., 2004; Mdee et al., 2009; Plodpai et al., 2013). The best MIC values obtained in this work are 38.5-56.8 times greater than those of the positive control (azoxystrobin): 6.25, 8.51, 7.78, and $5.77 \mathrm{mg} / \mathrm{mL}$ for L. achyranthifolia, A. subviscida, A. aurantium R-AcOEt, 
and $I$. murucoides, respectively. While mycelia growth inhibition $>50 \%$ was achieved by $A$. aurantium R-AcOEt and T. densiflora R. Species from the Verbenaceae, Euphorbiaceae, Asteraceae, Boraginaceae, and Convolvulaceae families were toxic to at least one of the fungal strains. Our results about toxic activity of T. densiflora and I. murucoides contribute to the scientific knowledge of plants with fungicide potential from the Boraginaceae or Convolvulaceae families. Previously, this activity was reported for Heliotropium floridum (Reyna et al., 1997), Cordia curassavica (Hernández et al., 2007), Ipomoea batatas (Stange et al., 2001) and I. carnea, whose latex possesses a quitinase (Patel et al., 2010). Whereas, examples of plants belonging to Euphorbiaceae (Niño et al., 2012; Ascacio-Valdés et al., 2013), Asteraceae and Verbenaceae (Hernández et al., 2008; Díaz-Dellavalle et al., 2011; Pupo-Blanco et al., 2011) with toxic activity on phytopathogens fungi are more common, particularly those from the Asteraceae family (Gamboa-Angulo et al., 2008; Nogueira et al., 2010; Carvalho et al., 2011).

\section{MYCELIAL GROWTH INHIBITION OF TREATMENTS AT SEVERAL CONCENTRATIONS}

From solubility tests, it was observed that all the extracts possessed a mixture of non-polar and polar constituents. Polar and non-polar mixtures were extracted with methanol, non-polar compounds were extracted using ether, $n$-hexanes $(\mathrm{Hx})$ and ethyl acetate (AcOEt), and water was used for the extraction of polar components from $H$. terenbithinaceus. Presence of non-polar compounds in the extracts limited their diffusion into the agar, which in turn caused that the activities of most of the extracts were dose-independent (Figures 2, 3). However, A. aurantium $\mathrm{R}$ AcOEt, E. acutifolia, and L. achyranthifolia extracts showed dosedependent activity against $F$. solani. The activity of $A$. aurantium and L. achyranthifolia extracts was reduced when the treatments were diluted in a 1:2 and 1:4 ratio (Figure 2). The effect of dilution of the A. subviscida extract on A. alternata was similar to that of E. acutifolia (Figure 3), whose inhibitory effect shifted to not inhibition and growth promotion when the treatments were diluted. This biphasic dose response was observed because growth stimulation happened at low doses and growth inhibition at high doses. This phenomenon is known as hormesis (Garzon and Flores, 2013) and has been described for some filamentous fungi as Fusarium oxysporum, Pythium aphanidermatum, and Penicillium expansum (Flores and Garzon, 2013) in mycelial growth tests.

\section{INHIBITORY ACTIVITY AGAINST B. LICHENIFORMIS}

In the current agroecologic practice, Bacillus strains are used to aid organic fertilizers and to control phytopathogens in commercial crops (Pérez-García et al., 2011), as well as to reduce the use of synthetic agrochemicals. Examples of such practices are the control of Ralstonia solanacearum in tomato crops by a Bacillus sp. strain (Wei et al., 2011) and the combination of Bacillus subtilis and Pseudomonas fluorescens (biocontrol agents) with extracts of Allium spp. to inhibit the mycelial growth of Alternaria solani (Latha et al., 2009). With the aim of finding an effective combination of a plant-derived fungicide and a biofertilizer bacteria, such as B. licheniformis, the toxicity of 12 plant extracts was tested against this strain. The extracts of $A$. aurantium, $A$. integrifolium, and $H$. terenbinthinaceus Aq did not have a significantly toxic activity against $B$. licheniformis. From these extracts, the antifungal treatments with greater potential are A. aurantium AcOEt since it was very active against mycelial growth of $F$. solani and $A$. alternata. In addition, A. integrifolium, A. aurantium $\mathrm{R}$, and $A$. aurantium $\mathrm{R}-\mathrm{AcOEt}$ had the greatest toxic activities against spores of $A$. alternaria with MIC values of 16.9, 20.0, and $7.8 \mathrm{mg} / \mathrm{mL}$, respectively.

\section{CONCLUSIONS}

The results suggest that among the plants studied, the most promising treatments for use in combination with Bacillus licheniformis are the A. aurantium roots AcOEt and A. integrifolium $\mathrm{MeOH}$ extracts. These extracts reduced the mycelial growth and sporulation of both pathogenic fungal strains: Fusarium solani and Alternaria alternata. In addition, the extracts of these plants did not affect the growth of the biofertilizer $B$. licheniformis and therefore possess an outstanding potential for the agroecologic control of fungal phytopathogens in industrial crops. Other extracts were toxic to $B$. liqueniformis but had antifungal activity against A. alternata (A. subviscida and L. achyranthifolia) and F. solani (I. murucoides). T. densiflora $\mathrm{R}$ had antifungal activity against both fungal strains. Therefore, these extracts can be used for the control of phytopathogen fungi in post-harvest foods as papaya (Bautista-Baños et al., 2013) and tomato (Feng et al., 2011). Further studies are needed to determine the bioactive compounds responsible for the antifungal activity of the extracts of A. aurantium, T. densiflora, A. subviscida, L. achyranthifolia, and I. murucoides.

\section{ACKNOWLEDGMENTS}

This work was supported by the PROMEP/103.5/12/6525 (Mexico) grant. We thank E. Cedillo-Portugal from the UACh, G. A. Salazar-Chávez, and J. Jiménez-Ramírez from the UNAM for performing plant taxonomic identifications. Karla I. Lira de León is grateful to the Instituto de Ciencia y Tecnología del Distrito Federal (México), and CONACyT (México) (No. 167267) for their financial support through the postdoctoral fellowship program.

\section{REFERENCES}

Alade, P. I., and Irobi, O. N. (1993). Antimicrobial activities of crude leaf extracts of Acalypha wilkesiana. J. Ethnopharmacol. 39, 171-174. doi: 10.1016/03788741(93)90033-2

Alonso-Castro, A. J., Villarreal, M. L., Salazar-Olivo, L. A., Gomez-Sanchez, M., Dominguez, F., and Garcia-Carranca, A. (2011). Mexican medicinal plants used for cancer treatment: pharmacological, phytochemical and ethnobotanical studies. J. Ethnopharmacol. 133, 945-972. doi: 10.1016/j.jep.2010. 11.055

Arnason, J. T., Bourque, G. J., Madhosilngh, C., and Orr, W. (1998). Disruption of membrane functions in Fusarium culmorum by an acetylenic allelochemical. Biochem. Syst. Ecol. 14, 569-574. doi: 10.1016/0305-1978(86)90035-9

Ascacio-Valdés, J., Burboa, E., Aguilera-Carbo, A. F., Aparicio, M., PérezSchmidt, R., Rodríguez, R., et al. (2013). Antifungal ellagitannin isolated from Euphorbia antisyphilitica Zucc. Asian Pac. J. Trop. Biomed. 3, 41-46. doi: 10.1016/S22211691(13)60021-0

Barnett, H. L., and Hunter, B. B. (1998). Illustrated Genera of Imperfect Fungi. 4th Edn. St. Paul, MN: APS Press. 
Bauer, A. W., Kirby, W. M., Sherris, J. C., and Turck, M. (1966). Antibiotic susceptibility testing by a standardized single disk method. Am. J. Clin. Pathol. 45, 493-496.

Bautista-Baños, S., Sivakumar, D., Bello-Pérez, A., Villanueva-Arce, R., and Hernández-López, M. (2013). A review of the management alternatives for controlling fungi on papaya fruit during the posharvest supply chain. Crop Prot. 49, 8-20. doi: 10.1016/j.cropro.2013.02.011

Bolívar, P., Cruz-Paredes, C., Hernández, L. R., Juárez, Z. N., Sánchez-Arreola, E., Av-Gay, Y., et al. (2011). Antimicrobial, anti-inflammatory, antiparasitic, and cytotoxic activities of Galium mexicanum. J. Ethnopharmacol. 137, 141-147. doi: 10.1016/j.jep.2011.04.069

Carvalho, D. D., Alves, E., Barbosa-Camargos, R., Ferreira-Oliveira, D., SoaresScolforo, J. R., Antônio de Carvalho, D., et al. (2011). Plant extracts to control Alternaria alternata in Murcott tangor fruits. Rev. Iberoam. Micol. 28, 173-178. doi: 10.1016/j.riam.2011.05.001

Chen, W.-Q., Song, Z.-J., and Xu, H.-H. (2012). A new antifungal and cytotoxic C-methylated flavone glycoside from Picea neoveitchii. Bioorg. Med. Chem. Lett. 22, 5819-5822. doi: 10.1016/j.bmcl.2012.07.089

Corona-Castañeda, B., Chérigo, L., Fragoso-Serrano, M., Gibbons, S., and PeredaMiranda, R. (2013). Modulators of antibiotic activity from Ipomoea murucoides. Phytochemistry 95, 277-283. doi: 10.1016/j.phytochem.2013.07.007.

Devi, P. A., Mohan, S., and Thiribhuvanamala, G. (2013). Antifungal activity of plant extracts against by Alternaria helianthi. J. Biopest. 6, 231-236.

Díaz-Dellavalle, P., Cabrera, A., Alem, D., Larrañaga, P., Ferreira, F., and Dalla-Rizza, M. (2011). Antifungal activity of medicinal plant extracts against phytopathogenic fungus Alternaria spp. Chilean J. Agric. Res. 71, 231-239.

Dimkić, I., Živković, S., Berić, T., Ivanović, Ž., Gavrilović, V., Stanković, S., et al. (2013). Characterization and evaluation of two Bacillus strains, SS-12.6 and SS13.1 , as potential agents for the control of phytopathogenic bacteria and fungi. Biol. Control 65, 312-321. doi: 10.1016/j.biocontrol.2013.03.012

Downum, K. R., Keil., D. J., and Rodríguez, E. (1985). Distribution of acetylenic thiophenes in the pectidinae. Biochem. Syst. Ecol. 13, 109-113. doi: 10.1016/0305-1978(85)90067-5

Ejechi, B. O., and Souzey, J. A. (1999). Inhibition of biodeterioration of yam tuber Dioscorea rotundata Poir in storage with phenolic extract of Acalypha hispida Burm.f. leaves. J. Stored Prod. Res. 35, 127-134. doi: 10.1016/S002247X(98)00038-1

Evans, C., Weir, D., Scaiano, J. C., Mac Eachern, A., Arnason, J. T., Morand, P., et al. (1986). Photochemistry of the botanical phototoxin, $\alpha$-terthienyl and some related compounds. Photochem. Photobiol. 44, 441-451. doi: 10.1111/j.17511097.1986.tb04691.x

Feng, W., Chen, J., Zheng, X., and Liu, Q. (2011). Thyme oil to control Alternaria alternata in vitro and in vivo as fumigant and contact treatments. Food Control 22, 78-81. doi: 10.1016/j.foodcont.2010.05.010

Ferreira-Medeiros, J. G., Costa-Araujo-Neto, A., Silva de Medeiros, D., Cordeiro do Nascimento, L., and Ursulino-Alves, E. (2013). Extratos vegetais no controle de patógenos em sementes de Pterogyne nitens Tul. Floresta Ambiente 20, 384-390. doi: 10.4322/floram.2013.029

Flores, F. J., and Garzon, C. D. (2013). Detection and assessment of chemical hormesis on the radial growth in vitro of oomicetes and fungal plant pathogens. Dose-Response 11, 361-373. doi: 10.2203/dose-response.12-026. Garzon

Gamboa-Angulo, M. M., Cristóbal-Alejo, J., Medina-Baizabal, I. L., Chí-Romero, F., Méndez-González, R., Simá-Polanco, P., et al. (2008). Antifungal properties of selected plants from the Yucatan peninsula, Mexico. World J. Microbiol. Biotechnol. 24, 1955-1959. doi: 10.1007/s11274-008-9658-x

Garzon, C. D., and Flores, F. J. (2013). "Hormesis: biphasic dose-responses to fungicides," in Plant Pathogens and Their Potential Threat to Agriculture, Fungicides Showcases of Integrated Plant Disease Management from Around the World, ed M. Nita (Europe: InTech.). doi: 10.5772/55359

Gastélum, R. F., and Gálvez-Figueroa, C. A. (2002). Control del moho negro, Alternaria alternata (Fr.:Fr.) en el fruto de tomate (Lycopersicon esculentum Mill.) considerando unidades calor y variables ambientales para la aplicación de Azoxystrobin en Sinaloa, México. Rev. Mex. Fitopatol. 20, 72-76.

Hernández, T., Canales, M., García, A. M., Duran, A., Meráz, S., Dávila, P., et al. (2008). Antifungal activity of the essential oils of two verbenaceae: Lantana achyranthifolia and Lippia graveolens of Zapotitlán de las Salinas, Puebla (México). Bol. Latinoam. Caribe Plant Med. Aromat. 7, 203-207.
Hernández, T., Canales, M., Teran, B., Avila, O., Duran, A., Garcia, A. M., et al. (2007). Antimicrobial activity of the essential oil and extracts of Cordia curassavica (Boraginaceae). J. Ethnopharmacol. 111, 137-141. doi: 10.1016/j.jep.2006.11.002

Jasso de Rodríguez, D., Hernández-Castillo, D., Angulo-Sánchez, J. L., RodríguezGarcía, R., Villarreal-Quintanilla, J. A., and Lira-Saldivar, R. H. (2007). Antifungal activity in vitro of Flourensia spp. extracts on Alternaria sp., Rhizoctonia solani, and Fusarium oxysporum. Ind. Crops Prod. 25, 111-116. doi: 10.1016/j.indcrop.2006.08.007

Jain, S. C., Singh, B., and Jain, R. (2000). Arnebins and antimicrobial activities of Arnebia hispidissima DC. cell cultures. Phytomedicine 6, 474-476. doi: 10.1016/S0944-7113(00)80077-X

Kourany, E., and Arnason, J. T. (1988). Accumulation of phototoxic thiophenes in Tagetes erecta (Asteraceae) elicited by Fusarium oxysporum. Physiol. Mol. Plant Pathol. 33, 287-297. doi: 10.1016/0885-5765(88)90029-X

Latha, P., Anand, T., Ragupathi, N., Prakasam, V., and Samiyappan, R. (2009). Antimicrobial activity of plant extracts and induction of systemic resistance in tomato plants by mixtures of PGPR strains and Zimmu leaf extract against Alternaria solani. Biol. Control 50, 85-93. doi: 10.1016/j.biocontrol.2009.03.002

Maya, C., and Thippanna, M. (2013). In vitro evaluation of ethno-botanically important plant extracts against early blight disease (Alternaria solani) of tomato. GJBB 2, 248-252.

Mdee, L. K., Masoko, P., and Eloff, J. N. (2009). The activity of extracts of seven common invasive plant species on fungal phytopathogens. S. Afr. J. Bot. 75, 375-379. doi: 10.1016/j.sajb.2009.02.003

Mojica-Marín, V., Luna-Olvera, H. A., Sandoval-Coronado, C. F., Pereyra-Alférez, B., Morales-Ramos, L. H., González-Aguilar, N. A., et al. (2009). Biological control of chili pepper root rot (Capsicum annuum L.) by Bacillus thuringiensis. Phyton 78, 105-110.

Navarro-García, V. M., González, A., Fuentes, M., Aviles, M., Rios, M. Y., Zepeda, G., et al. (2003). Antifungal activities of nine traditional Mexican medicinal plants. J. Ethnopharmacol. 87, 85-88. doi: 10.1016/S0378-8741(03)00114-4

Niño, J., Mosquera, O. M., and Correa, Y. M. (2012). Antibacterial and antifungal activities of crude plant extracts from Colombian biodiversity. Rev. Biol. Trop. 60, 1535-1542.

Nirenberg, H. (1976). Untersuchungen über die morphologische und biologische Differenzierung in der Fusarium-Sektion Liseola. Mitteilungen aus der Biologischen Bundesanstalt für Landund Forstwirtschaft Berlin-Dahlem $169,1-117$.

Nogueira, J. H. C., Gonçalez, E., Galleti, S. R., Facanali, R., Marques, M. O. M., and Felício, J. D. (2010). Ageratum conyzoides essential oil as aflatoxin suppressor of Aspergillus flavus. Int. J. Food Microbiol. 137, 55-60. doi: 10.1016/j.ijfoodmicro.2009.10.017

Osuna, L., Tapia-Pérez, M. E., Jiménez-Ferrer, J. E., Carrillo-Quiroz, B. A., and Silva-Sánchez, J. (2005). Screening of Alternanthera repens, Boerhavia coccinea, Flaveria trinervia, Tornefortia densiflora, and Vitex mollis. Extracts to evaluate their antibacterial activity and effect on smooth muscle. I. Pharm. Biol. 43, 749-753. doi: 10.1080/13880200500406412

Patel, K. A., Singh, V. K., Yadav, R. P., Moir, A. J. G., and Jagannadham, M. V. (2010). Purification and characterization of a new chitinase from latex of Ipomoea carnea. Process Biochem. 45, 675-681. doi: 10.1016/j.procbio.2009.12.016

Pérez-García, A., Romero, D., and de Vicente, A. (2011). Plant protection and growth stimulation by microorganism: biotechnology applications of Bacilli in agriculture. Curr. Opin. Biotechnol. 22, 187-193. doi: 10.1016/j.copbio.2010.12.003

Pinto, C. M. F., Maffia, L. A., Casali, V. W. D., and Cardoso, A. A. (1998). In vitro effect of plant leaf extracts on mycelial growth and sclerotial germination of Sclerotium cepivorum. J. Phytopathol. 146, 421-425. doi: 10.1111/j.14390434.1998.tb04775.x

Plodpai, P., Chuenchitt, S., Petcharat, V., Chakthong, S., and Voravuthikunchai, S. P. (2013). Anti-Rhizoctonia solani activity by Desmos chinensis extracts and its mechanism of action. Crop Prot. 43, 65-71. doi: 10.1016/j.cropro.2012.09.004

Pupo-Blanco, Y. G., Kalombo-Bicayi, D., Herrera-Isla, L., Malheiros de Mendonca, D. I., and Vargas-Batis, B. (2011). Effect of plant extracts on growth and spore germination of Alternaria solani (E. \& M.) J. \& G. under in vitro conditions. Rev. Iberoam. Micol. 28, 60. doi: 10.1016/j.riam.2010.10.004

Reddy, K. H., Sharma, P. V. G. K., and Reddy, O. V. S. (2010). A comparative in vitro study on antifungal and antioxidant activities of Nervilia aragoana and Atlantia monophylla. Pharm. Biol. 48, 595-602. doi: 10.3109/13880200903218927 
Reyna, M., Gozalez-Coloma, A., Gutierrez, C., Cabrera, R., Henriquez, J., and Villarroel, L. (1997). Bioactive satured pyrrolizidine alkaloids from Heliotropium floridum. Phytochemistry 46, 845-853. doi: 10.1016/S0031-9422 (97)00354-3

Saito, T. K., Takahashi, M., Muguruma, H., Niki, E., and Mabuchi, K. (2001). Phototoxic process after rapid photosensitive membrane damage of

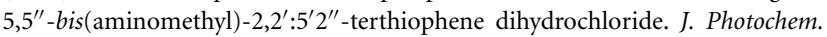
Photobiol. B 61, 114-121. doi: 10.1016/S1011-1344(01)00167-1

Santos-Sánchez, N. F., Flores-Parra, A., Valadez-Blanco, R., Fernández-Rojas, B., Martínez-Vásquez, J. B., and and Salas-Coronado, R. (2014). Polyphenolic content, free radical-scavenging activity and isolation of tiliroside from Heliocarpus terebinthinaceus (Tiliaceae) seeds. J. Biol. Sci. 14, 376-380. doi: 10.3923/ jbs. 2014

Sánchez, V., Rebolledo, O., Picaso, R. M., Cárdenas, E., Córdova, J., González, O., et al. (2007). In vitro antagonism of Thielaviopsis paradoxa by Trichoderma longibrachiatum. Mycopathologia 163, 49-58. doi: 10.1007/s11046-0060085-y

Sasidharan, S., Latha, L. Y., Ping, K. Y., and Lachumy, S. J. (2012). “Screening methods in the study of fungicidal property of medicinal plants," in Fungicides for Plant and Animal Diseases, ed D. Dhanasekaran (Shanghai: InTech.), 107-118. doi: $10.5772 / 25714$

Shimura, H., Matsuura, M., Takada, N., and Koda, Y. (2007). An antifungal compound involved in symbiotic germination of Cypripedium macranthos var. rebunense (Orchidaceae). Phytochemistry 68, 1442-1447. doi: 10.1016/j.phytochem.2007.03.006

Srivastava, D., and Singh, P. (2011). Antifungal potential of two common weeds against plant pathogenic fungi- Alternaria sps. Asian J. Exp. Biol. Sci. 2, 525-528.

Stange, R. R. Jr., Midland, S. L., Holmes, G. J., Sims, J. J., and Mayer, R. T. (2001). Constituents from the periderm and outer cortex of Ipomoea batatas with antifungal activity against Rhizopus stolonifer. Postharvest Biol. Tech. 23, 85-92. doi: 10.1016/S0925-5214(01)00105-3
Stanković, M., Radojeviić, I., Ćurčić, M., Vasić, S., Topuzović, M., Ćomič, L., et al. (2012). Evaluation of biological activities of goldmoss stonecrop (Sedum acre L.). Turk. J. Biol. 36, 580-588. doi: 10.3906/biy-1109-9

Svetaz, L., Tapia, A., López, S. N., Furlán, R. L. E., Petenatti, E., Pioli, R., et al. (2004). Antifungal chalcones and new caffeic acid esters from Zuccagnia punctata acting against soybean infecting fungi. J. Agric. Food Chem. 52, 3297-3300. doi: 10.1021/jf035213x

Wei, Z., Yang, X., Yin, S., Shen, Q., Ran, W., and Xu, Y. (2011). Efficacy of Bacillusfortified organic fertilizer in controlling bacterial wilt of tomato in the field. Appl. Soil Ecol. 48, 152-159. doi: 10.1016/j.apsoil.2011.03.013

Woudenberg, J. H. C., Groenewald, J. Z., Binder, M., and Crous, P. W. (2013). Alternaria redefined. Stud. Mycol. 75, 171-212. doi: 10.3114/sim0015

Conflict of Interest Statement: The authors declare that the research was conducted in the absence of any commercial or financial relationships that could be construed as a potential conflict of interest.

Received: 22 April 2014; accepted: 09 July 2014; published online: 05 August 2014. Citation: Lira-De León KI, Ramírez-Mares MV, Sánchez-López V, Ramírez-Lepe M, Salas-Coronado R, Santos-Sánchez NF, Valadez-Blanco $R$ and Hernández-Carlos $B$ (2014) Effect of crude plant extracts from some Oaxacan flora on two deleterious fungal phytopathogens and extract compatibility with a biofertilizer strain. Front. Microbiol. 5:383. doi: 10.3389/fmicb.2014.00383

This article was submitted to Food Microbiology, a section of the journal Frontiers in Microbiology.

Copyright (C) 2014 Lira-De León, Ramírez-Mares, Sánchez-López, Ramírez-Lepe, Salas-Coronado, Santos-Sánchez, Valadez-Blanco and Hernández-Carlos. This is an open-access article distributed under the terms of the Creative Commons Attribution License (CC BY). The use, distribution or reproduction in other forums is permitted, provided the original author(s) or licensor are credited and that the original publication in this journal is cited, in accordance with accepted academic practice. No use, distribution or reproduction is permitted which does not comply with these terms. 